This is an electronic version of an article published in Zygon. Journal of Religion and Science 45 (4), 791-816.

\title{
Creationism in the Netherlands
}

\section{Introduction}

Creationism and strong anti-evolutionism are often regarded as typically North American phenomena. In the United States, creationists are numerous and very well organized, and they form a considerable political pressure group. However, more and more reports indicate that creationism is dispersing globally, often as the result of missionary work by American creationist groups. In the last three decades, creationism has popped up in Canada, Australia, New Zealand, South Korea (Numbers 2006), and, last but not least, in Europe (CornishBowden and Cárdenas 2007; Curry 2009; Kjaergaard 2008; Numbers 2006). Germany and Poland are but two examples of European countries that have seen their share of creationist activity (Graebsch 2006; Kutschera 2008). In this article, we will focus on creationism in yet another European country, the Netherlands. Several incidents, both large and small, in the last couple of years indicate that Dutch creationism is a socio-religious phenomenon that cannot be ignored. Here, I will discuss three major events.

First, we will see how Intelligent Design (ID) creationism was introduced into the Dutch public sphere by a renowned physicist, Cees Dekker. Dekker caused a political row, indirectly, in 2005 when the then-Minister of Education, after talking to Dekker, expressed her hope that, eventually, ID might be incorporated into the school curriculum. One year later, however, Dekker himself was gradually shifting towards more evolution-friendly opinions; he was followed in that shift by a well-known media personality, Andries Knevel. This brings us to our second point. Knevel is not an academic, but one of the most important figures within 
the Dutch evangelical broadcasting group, the Evangelische Omroep (EO). The EO created its identity during the 1970s by promoting young-Earth creationism. When Knevel publicly abandoned this belief and embraced ID in 2005, young-Earth creationists were not amused by his conversion. They were even less impressed when, in February 2009, Knevel confessed that he was sorry for having misled his public by promoting both young-Earth creationism and ID. By then, young-Earth creationist organizations had become very active, provoked by the impending year of celebration of the work of Charles Darwin in 2009, the bicentenary of the scientist's birth. They had already started an ambitious project to make sure that the Dutch people would hear of the so-called 'alternatives' to evolutionary theory.

\section{The rise and fall of Intelligent Design: The story of Cees Dekker}

\section{Intelligent Design on the way in}

In March 2005, ID entered the public arena in the Netherlands. Maria Van der Hoeven, a member of the Christian democratic party CDA, and at that time Minister of Education, Culture and Science, wrote on her weblog that she had had an interesting talk with Cees Dekker, an evangelical and a Dutch scientist with ID sympathies. Dekker still works as a professor at the Delft University of Technology where he specializes in nanotechnology, the manipulation of materials at microscopic level. During the last 10 years, however, he has shifted to single-molecule biophysics. His list of publications is impressive ${ }^{1}$, and in 2003 he was awarded the Spinoza Prize, a high-level scientific, to which the editor of the biological journal Bionieuws afterwards objected that "allowing fanatical creationists is a disastrous road to take" and that "Cees Dekker has to get out" (quoted in Smedes 2005, 119).

Van der Hoeven felt very impressed with the way Dekker could combine science with religion, and she confessed that she herself could not believe in 'chance'. She explained: 
"What connects Islam, Judaism and Christianity is the idea that there is a Creator, no matter how he is identified. In this, I recognize a possibility to build bridges. This can especially be achieved within academic discussions. If we succeed in uniting scientists adhering to all kinds of faith, then it might even become applied in schools and lessons. People from my administration will talk this through with Dekker, to decide on how we should shape this debate." 2

Two months later, she declared, "It should be understood that evolutionary theory is incomplete and that we are still discovering new things", and that she hoped to instigate a dialogue between scientists and proponents of ID. ${ }^{3}$ Her proposition, however, was met with severe criticism by both scientists and politicians, leading her to withdraw her plans. Nevertheless, on June 8, 2005, at the release of Schitterend ongeluk, of sporen van ontwerp? (Glorious accident, or traces of design?), a book edited by Cees Dekker, Ronald Meester and René van Woudenberg, Maria van der Hoeven was still very hopeful that she would succeed in organizing a public debate. In her speech at the book release, she expressed her concern with fostering a greater mutual respect among people with different philosophical backgrounds. ${ }^{4}$

The incident drew international attention. The people from the Discovery Institute, the Seattle think tank that promotes ID, were very pleased with the introduction of their ideas in a European country. On his website, Uncommondescent.com, William Dembski, one of the primary American ID proponents, proudly announced in May 2005 that "there are further indicators that ID is internationalizing". He also wrote that he was "aware of a forthcoming multi-contributor edited collection by Dutch scientists focused on turning ID into a fullfledged research program [by which he presumably meant the book mentioned above; see also below]. It's developments like these which lead me to think that what happens with the school 
boards and court battles will not be decisive. These ideas have a momentum that no amount of complaining by the Darwinists will stop."5

An article in Science asked ironically whether Holland was becoming the Kansas of Europe (Enserink 2005). Two years later, the incident with Van der Hoeven was mentioned, among many other incidents from all over Europe, in the working documents ${ }^{6}$ that resulted in Resolution 1580, in which the Council of Europe warned against "The dangers of creationism in education". 7

On November 17, 2000, Dekker had addressed his doubts concerning the scientific status of evolutionary theory in his inaugural speech $^{8}$. Although Dekker admitted that his own research did not involve Darwinian theory, he nevertheless felt knowledgeable enough to judge that “there is remarkably little scientific support for such an important theory like Darwin's evolutionary mechanism". 9 He also claimed that "evolution, defined as the explanation for the origin of life and the origin of biodiversity, is a dogma that, after careful examination, barely has any scientific support. At its best, the evidence is sporadic." ${ }^{10}$ As he referred to the works of ID proponents Michael Denton ${ }^{11}$, Michael Behe and Phillip Johnson, it is not hard to see where he had retrieved his information. The published speech even reproduces (at page 19) the schematic image of a flagellum, the poster-child of the ID movement, which was introduced by Michael Behe in his book, Darwin's black box, in 1996.

The same year, on March 24, 2000, there had already been another inaugural address in which Darwinian theory was under attack. The speaker was Ronald Meester, professor at the Department of Mathemathics at the VU University Amsterdam. ${ }^{12}$ In his address, he stated that “on a popular level Darwin is still very much alive, but [that] on an academic level, there are many, many doubts". ${ }^{13}$ In a footnote, he, too, refers to Denton's and Behe's works, of which he had learned through the works of the Dutch professor-emeritus Arie Van den Beukel, once 
a physicist at Delft University of Technology - the same university as Dekker. Van den Beukel had popped up in Dekker's speech as the person who had introduced Dekker to ID. In the early 1990s, Van den Beukel had written two books expressing his views on science and religion. The first, De dingen hebben hun geheim (Things have their secrets), was published in 1990. In this book, his main concern lay with the "materialism" and "reductionism" of modern science, which, in his view, leave the world without a deeper meaning. However, in his second book, Met andere ogen (With different eyes), published in 1994, his specifically anti-Darwinian sentiments had grown. Relying heavily on Denton's Evolution. A theory in crisis, which he does not mention in his 1990 book, Van den Beukel argued that Darwinian theory lacked any hard evidence and that the theory was adhered to as though it were some kind of faith. In 1997, he wrote the introduction to the Dutch translation of Behe's Darwin's black box (Behe 1997). Van den Beukel can be rightly considered the pioneer of ID in the Netherlands.

These ideas were picked up independently by both Dekker and Meester. At the time of their speeches, neither was aware of the fact that they shared similar views. This changed when, two years later, a piece on ID appeared in Skepter, the magazine of the Dutch skeptic group, Skepsis. In this article, journalist Marcel Hulspas called ID a more sophisticated kind of creationism, and he made clear that it definitely was not science. He mentioned the inaugural addresses of Meester and Dekker as indications of the fact that ID did have supporters in the Netherlands (Hulspas 2002). Meester and Dekker consequently joined forces to write a response. They argued for keeping an open mind towards ID, which they defined as an "alternative concept" that had "a very old history that could be traced all the way back to Aristotle" (Dekker and Meester 2002, 42). To them, equating ID with creationism made no sense because "it is concluded from scientific observations and reasoning that design must be 
fundamental to the natural reality we experience" (Dekker and Meester 2002, 43). They complained that the 'Darwinian mechanism' was still accepted although no evidence supported it, because it fitted in well with a materialist-atheist worldview (Dekker and Meester 2002, 44). In turn, their reaction provoked some heavy criticism both in the magazine $^{14}$ and other media (Dekker 2005, 61). Eventually, the debate faded out, only to reoccur in 2005. In the meantime, Dekker and Meester were joined by the philosopher René van Woudenberg who, in his inaugural speech at the VU University Amsterdam in 2002, argued that ID was a sensible concept that could easily be combined with 'chance' (Dekker 2005, 62; Van Woudenberg 2002), which he repeated in a book one year later (Van Woudenberg 2003). Soon they and other Christian scientists were meeting monthly to discuss all kinds of topics relating to science and religion. They called themselves the 'Baambrugge group' (Dekker 2008, 328). Inspired by the ideas that were discussed at these meetings, they started compiling articles that would become the 2005 book on ID, Schitterend ongeluk of sporen van ontwerp.

\section{A glorious accident}

Although some of the authors who contributed articles did not entirely share the editors' views on design, this book can easily be considered a Dutch defense of ID. With Dekker authoring three articles, Meester and Van Woudenberg two each, and Van den Beukel one article, the content and tone were strongly anti-Darwinian. In the introduction, they insisted that their defense of ID was inspired only by the power of scientific argument, not by religious prejudice (Dekker et al. 2005, 11). However, once one begins reading the book, one soon sees clearly that they did not derive their arguments from mainstream science. American proponents of ID are quoted throughout the entire book. The arguments against evolutionary theory were directly imported from books by Phillip Johnson, Michael Behe, and William 
Dembski. Dekker and his companions were either unaware of or were ignoring the fact that by 2005 , their arguments against evolutionary theory and for ID had already been entirely demolished by numerous scientists and philosophers in the United States (e.g. Forrest and Gross 2004; Miller 1999; Pennock 1999, 2001; Young and Edis 2004;). Six months after the publication of the book, ID suffered a serious blow in court in the case of Kitzmiller vs. Dover, the 'Dover trial', when Judge John E. Jones III ruled that the teaching of ID in government school science classes violates the First Amendment of the U. S. Constitution because it is not a scientific but a religious view (Numbers 2006).

The efforts of Dekker and his co-workers did not pass unnoticed, however. On October 22, 2005, Dekker delivered a talk at a conference in Prague, the capital of the Czech Republic. The title of the conference was 'Darwin and design' 15 and it was organized by Charles and Carole Thaxton. In 1984, Charles Thaxton had co-authored, The mystery of life's origin. Reassessing current theories, which is now considered, together with Denton's Evolution. A theory in crisis, one of the seminal works of the ID movement (Numbers 2006, 374). On Dembski's website we read that "Cees Dekker (...) gave a short but well-illustrated presentation on molecular machines". ${ }^{16}$ It appears that he filled in for Michael Behe, who was at that time giving testimony in the Dover trial. Other speakers included Stephen Meyer, Jonathan Wells, Charles Thaxton, and David Berlinski, who are all still closely tied to the Center for Science and Culture (CSC), a subsidiary of the Discovery Institute through which the ID movement operates. Moreover, Meyer is the program director of the $\mathrm{CSC}^{17}$, so it seems that the conference was indeed very important to them. Since hundreds of people from 18 different nations from all over the world attended the conference ${ }^{18}$, the importance that the CSC attached to the conference is not surprising. To Dembski, the Prague conference "clearly demonstrated that the intelligent design controversy is not just an American phenomenon; it 
opened many doors to colleagues in Europe with whom the ID community will be working extensively in the years to come". 19

In the context of the strategy of importing ID into Europe, the efforts made by Dekker seemed very promising indeed. Even after the Dover trial, Dekker, who knew of the devastating verdict, publicly defended ID. On January 1, 2006, he and Ronald Meester were featured in a program on Dutch national television called Buitenhof (VPRO), where they discussed ID with several skeptical Dutch scientists. Dekker maintained that there was a genuine, ongoing scientific debate on whether there are objective criteria for detecting design in biological systems. He found it hard to accept that the information content of a cell was the product of 'mere chance'. He thought ID was an interesting approach that he wanted to give a fair chance, yet he doubted whether its methods would ever prove successful. ${ }^{20}$

\section{But is it science?}

Two months later, on February 28, 2006, in yet another television show, Het elfde uur (broadcast by the evangelical group, EO; see below), Dekker declared that he could not discern any conflict between science and religion. In his eyes, there only existed a cultural conflict between the atheistic, secular worldview and the theistic, Christian worldview. That was, in short, the message of the article he had written for a brand new book that he had edited with Ronald Meester and René Van Woudenberg, En God beschikte een worm (And God prepared a worm). ${ }^{21} \mathrm{He}$ had released the book only a couple of hours before he went on television, which was the reason he was invited to appear. He was accompanied by Sander van Doorn, a Christian evolutionary biologist and contributing author to the new book, who defended the compatibility of Christian faith with evolutionary theory. ${ }^{22}$ 
It seemed that ID was replaced by a more moderate position. The book, however, reveals a slightly different, more nuanced picture. Although Dekker wrote that "Christians fight for the wrong cause if they fight against evolutionary biology" (Dekker 2006, 363) and that "there is no conflict between faith and science" (Dekker 2006, 362), he certainly used a great deal of material from books by Phillip Johnson, the founder of the ID movement in America. Just like Johnson in Darwin on trial and Reason in the balance, Dekker set the naturalistic worldview against the theistic worldview (Dekker 2006, 365; Johnson 1991, 8; Johnson 1995, 88 and 109). He depicted naturalism as atheism, materialism, scientism, physicalism, modernism, and secular humanism (Dekker 2006, 364; compare, for instance, with Johnson 1995, 37, 38, 40, $51-70$, etc.) and referred to the first verses of the New Testament Gospel of John ${ }^{23}$ as fundamental to the theistic worldview (Dekker 2006, 369; Johnson 1995, 107). The fact that Dekker had not entirely abandoned ID and was still very much influenced by Johnson's writings is illustrated by the following passage:

Certain complex cell structures pose great difficulties for the traditional neoDarwinian scenario. You would expect that alternative explanations would be welcome. For some people however, all questions have been answered a priori by the solution that 'Darwin has already explained it'. It is amazing that so many intellectually gifted colleagues, who, as skeptical scientists, are well-trained in critical thinking, find the limited 'standard evidence' for Darwinism (the trivial microevolution in Kettlewell's moths, in Darwin's finches on the Galapagos, in bacteria that become resistant against antibiotics) so convincing as evidence for the fact that the formidable diversity of the entire biological world has come about through neoDarwinian macro-evolution. (Dekker 2006, 373-4) [my translation] 
Dekker was not the only author in the book who was still sympathetic to ID. Co-editor Van Woudenberg argued that creation and evolution were indeed compatible, but he also wrote that Denton"s Evolution. A theory in crisis is "an indispensable book to determine which attitude suited most in approaching evolutionary theory" (Van Woudenberg 2006, 197). In the conclusion of a rather vague article, the other co-editor, Ronald Meester, summarized his position towards evolutionary theory:

I believe that evolution has taken place, but I do not think that we will ever understand how it all could have happened through scientific means. Of course, this does not make me a creationist (...) and it does not make me an Intelligent Design proponent. At some points, the ID movement does some excellent work, and therefore I have defended it at these points. In particular, it is successful in attacking the popular notion that evolutionary biologists only need to fill in some small 'gaps'. There are serious, fundamental problems with a pure Darwinian scenario as an explanation for 'everything', and to point this out is very wise. However, I do not leap to a designer (...). (Meester 2006, 296)[my translation]

Not all authors shared these ambivalent feelings. The most straightforward was Van den Beukel, arguing that Michael Behe had convincingly demonstrated that "the origin of some of those (so-called irreducibly complex) mechanisms cannot possibly be explained by the standard mechanism of Darwin (mutation and natural selection), and that the best explanation is that they are the result of Intelligent Design" (Van den Beukel 2006, 205). Although some authors argue in the book for distinct realms for science and religion (e.g. Smedes 2006), En God beschikte een worm was clearly still very much an ID book.

Surprisingly and unexpectedly, however, on April 14, 2006, two months after the release of the book, Dekker distanced himself completely from ID. In an article on the website of 
Nederlands Dagblad, a Dutch Christian newspaper, he said that he was very disappointed in ID's lack of practical application and complained that his name had become inappropriately associated with it. He stated clearly that he did not adhere to ID, raising the question of what had caused him to change his views so abruptly. ${ }^{24}$

\section{Intelligent Design on the way out}

Dekker now considers himself a theistic evolutionist, someone who accepts evolutionary theory but thinks that God works through evolutionary processes (Dekker 2008). Dekker was in part drawn to this position after reading Francis S. Collins' The language of God, in which Collins, director of the National Human Genome Research Institute from 1993- 2008, defends the compatibility of science and Christian faith. Dekker showed himself to be very enthusiastic about this book and wrote the foreword of the Dutch translation (Collins 2006). ${ }^{25}$ Theistic evolution, however, is completely rejected by the main proponents of ID. They frequently blame theistic evolutionists for making God utterly redundant. Dembski, for instance, asserts that "within theistic evolution, God is a master of stealth who constantly eludes our best efforts to detect him empirically" (Dembski 1999, 110). To him and other ID advocates, theistic evolution is simply unacceptable. Dekker, however, was no longer one of them.

On October 3, 2007, Dekker's book Omhoog kijken in Platland (Looking up in Flatland ${ }^{26}$ ) was published, completing the trilogy that had begun in 2005 with Schitterend ongeluk, of sporen van ontwerp (Knevel 2007, 328). In his own article, Dekker questioned the increasing importance of technology in human lives because it made no room for the "depth of humanity" (Dekker 2007, 280). He feared that Western culture was turning into a "brave new world", as described by Aldous Huxley in 1932. As a Christian, he accepted the application of technology to cure people, but not to improve them. There was not a single reference to ID, 
Johnson, Behe, or Dembski (Dekker 2007). Moreover, ID and the names of any of its American proselytizers were left unmentioned throughout the entire book. Omhoog kijken in Platland is intended to show that orthodox Christian faith - orthodox, as in contrast with liberal, modernistic interpretations of Christian faith - can be coherently combined with modern science. The focus is no longer on the tension between creation or design and evolution (Dekker et al. 2007, 15-16). Only one chapter, written by Pieter Smelik, a Protestant physician, deals with the question of evolutionary theory. Smelik claims to accept the fact of evolution but thinks that the mechanism that drives evolution is still obscure. He writes: "Evolutionary theory explains adaptive changes (micro-evolution) perfectly well, but it does not make it apprehensible that adaption processes can lead up to an entire new building plan, nor can it (yet) explain the emergence of new genes to create new features" (Smelik 2007, 178). Because evolution can mean different things to different people, it is not always easy to determine what people exactly mean when they claim to have accepted it. Smelik describes evolution as "a creating evolution, a dynamic disclosure of reality, inspired (not dictated!) by the divine Mind. The creature becomes creative, enriches itself with stocked information and searches, thus creating itself, a way through history" (Smelik 2007, 179). This might be some form of evolution, but it is certainly not evolutionary theory in any scientific sense.

What did Dekker himself think of evolutionary theory? What did he now accept? From his chapter in the 2007 book it is hard to tell. When he appeared in a television show on October 9, 2007, on the EO to talk about the book, he said that science was a very powerful method to obtain knowledge but that it could not disprove God. He thought that faith and science fitted together beautifully. However, he said not a word concerning his exact stance towards evolutionary theory. ${ }^{27}$ One year later, in yet a fourth book, Geleerd en gelovig (Learned and religious), we find a precise formulation of his new position as a theistic evolutionist. He 
wholly believed that "God was Creator, and that He created through processes of evolution" (Dekker 2008, 331). To Dekker as a scientist, the evidence for evolution was overwhelming: "For the evolution of life there is all kinds of proof, the fossils, homologies, the geographic distribution of species, and genetics" (Dekker 2008, 331). Unlike Smelik, Dekker also seemed to have accepted natural selection as a natural law that was initiated by God: "Theistic evolution includes the idea that we investigate nature with the help of science, the human activity in which we use our mind, given to us by our Creator to grasp His creation. Simultaneously, it includes the strong faith that God is the author of those natural laws, that he is truly creator. God is sovereign and almighty and could create in any way He chooses, but he has apparently chosen to create mainly by secondary causes, by processes that we describe by natural laws.” (Dekker 2008, 333) [my translation]

Before the book came out in December 2008, he had already portrayed himself as a theistic evolutionist in two interviews with Reformatorisch Dagblad, a newspaper with a very conservative Protestant audience. ${ }^{28}$ He now thought of Darwin as a "fantastic scientist", who had a "brilliant insight in biology" and "discovered natural laws like natural selection". ${ }^{29} \mathrm{On}$ January 6, 2009, Dekker took part in an EO discussion program on Dutch national television, together with an atheistic, Darwinian philosopher and a young-Earth creationist. The show was intended as a special edition to kick off the year of Charles Darwin. The host of the show, Andries Knevel, introduced Dekker as a Christian who reconciled God and Darwin. Dekker had come a long way from Intelligent Design.

\section{Andries Knevel and the Evangelical broadcaster: The struggle over science and Genesis}

\section{Knevel and the EO: an introduction}


It was not a mere coincidence that Dekker was invited to appear as a theistic evolutionist in Knevel's show. Knevel and Dekker had known each other for at least a couple of years. Every time Dekker had published a book, Knevel had given him the opportunity to come and talk about it on television. ${ }^{30}$ Knevel had spoken at Dekker's book release in June $2005^{31}$ and acted as a moderator at the release of Omhoog kijken in Platland in October 2007. Dekker and Knevel had also worked together on several other projects (Knevel 2007, 145-7). They seemed to be bound by at least one common interest: how to reconcile their orthodox faith with science. In answering this question, Knevel underwent somewhat the same shift in thinking as Dekker. However, Knevel was in a position very different from Dekker's. Therefore, his intellectual transformation generated an entirely different response from an entirely different corner.

Knevel started working for the Evangelische Omroep (the EO, the evangelical broadcaster) in 1978. At that time, the EO was still young; it had been broadcasting only since 1970. When Knevel arrived, the EO had just established itself as a medium for orthodox, evangelical Christians. During the two previous decades, these Christians had already developed a strong resentment against evolutionary theory (Flipse 2009). One of the issues on which they wanted to have an influence was the literal interpretation of the story of Genesis. In 1977, the EO made a documentary, Adam of aap? (Adam or ape?) ${ }^{32}$, in which young-Earth creationism was defended with the assistance of the late A. E. Wilder-Smith, a well-known British creationist. ${ }^{33}$ The same year, the EO also organized a public debate with the title Schepping of evolutie? (Creation or evolution?) in the Jaarbeurs Congrescentrum in Utrecht. Three Dutch pro-evolution scientists (an astronomer, a geologist and a biologist) were pitted against three American creationists, Duane Gish being one of them. The debate was later aired on television. ${ }^{34}$ In his book, Avonduren (Evening hours), Knevel recalls this period: 
Meanwhile the EO started broadcasting and it was stressed during the seventies that Christian faith exclusively implied a young Earth. (...) The literal reading of Genesis with the numbers of six or ten thousand years became an identification mark for a movement of which the EO was at the core. (...) When I started working for the EO as a freelancer in March 1978, I found myself in the aftermath of that antithetical period - at least concerning that topic - and I immediately felt at home. There was yet another congress with the title Adam or Ape, but the climax had already passed. Other issues were setting the agenda (from abortion to nuclear missiles). (...) The theme 'Creation or evolution' was no longer fascinating to me. By then, I thought I had seen it all. That position lasted during the entire eighties. (Knevel 2007, 226-7) [my translation]

Knevel was not the only one who had lost interest in the debate on creationism by the beginning of the 1980s. After the EO had paid so much attention to the defense of youngEarth creationism against both more liberal interpretations of the Bible and evolutionary theory during the 1970 s, creationism was no longer an issue. A decade of silence began. ${ }^{35}$

\section{Knevel and Intelligent Design}

Things started changing in the 1990s. In 1990 and 1994, Arie van den Beukel published his two books in which he introduced ID to many Dutch conservative Christians. His work not only influenced Cees Dekker and Ronald Meester, but also Andries Knevel, who had by then had made a splendid career in the EO, becoming one of its three co-directors in 1993. For Knevel, reading Van den Beukel's books was an awakening that made him aware of other possible positions regarding creation. ${ }^{36}$ He began acknowledging the evidence for an old Earth and found out through the Internet that many conservative Christians in the United States had no problem with it. They could easily accommodate their faith with an old Earth. The greatest shock for Knevel came when he read Michael Behe's Darwin's black box. 
Knevel realized that there existed respectable alternatives to a young-Earth creationism that neither infringed on Christian faith nor entailed the acceptance of the purely naturalistic account of evolutionary theory. Slowly, his faith in a young Earth started waning as he moved towards ID (Knevel 2007, 227-8).

However, Knevel was still struggling with this change of heart. By the end of the 1990s, he was asked by the EO to travel to the United States. He took this opportunity to visit some Christian scientists, including several fellows of the Center for Science and Culture, for example, Walter Bradley and William Dembski, to ask them in person how they dealt with these issues. Most of them accepted an old Earth, and Knevel ended up even more confused. His conversion to ID was completed only when he was back in Holland and organized a meeting with several Dutch Christian scientists to discuss the potential role of ID within the EO. At that meeting, one of the participants corrected Knevel on the exact age of the universe and the Earth. Knevel hesitantly had used some imprecise figures, but he was promptly told that the exact numbers were 13.7 billion and 4.5 billion years, respectively. After that remark, Knevel realized that he was no longer a young-Earth creationist: "That day I accepted the socalled results of science. An old Earth and an old universe. That afternoon I left creationism behind and confessed to adhering to Intelligent Design, without knowing exactly what ID stood for. Through the years I had never doubted that God was the creator of heaven and Earth. He has created. The question was how." (Knevel 2007, 230) [my translation] At the presentation of Dekker's Schitterend ongeluk on June 8, 2005, Knevel spoke out publicly for ID for the first time. Three days later, in an EO radio program, he argued for a debate between young-Earth creationists and ID proponents. He considered ID to be a beautiful solution to reconcile science with a belief in Genesis. The debate, however, never took place. From the start, young-Earth creationists were not very keen on embracing ID. 
Koos van Delden, one of the makers of the Adam of Aap? documentary, was featured with Knevel in the radio show. Van Delden had not abandoned the literal reading of Genesis at all. Therefore, he thought it foolhardy of Christians to regard ID proponents as allies to their cause. ID proponents omitted a part of the biblical truth, and he found that very inconsistent. He also compared ID to a car without a motor, and therefore a car without much use. ${ }^{37}$

Soon Knevel learned that ID was perhaps not the beautiful solution that he had first hoped it would be. Instead of reconciling Christian faith with science and "effectively attacking the Darwinian bastion" (Knevel 2007, 231), ID seemed to engender some serious fractures within Dutch orthodox Christianity. In the United States, Phillip Johnson and his co-workers at the CSC, intended ID to act as a 'big tent', embracing both young and old-Earth creationism. That way, ID was supposed to function as a wedge that could split the log of Darwinian naturalism and secular culture (Forrest and Gross 2007). In the US, however, many young-Earth creationists objected to ID on theological grounds; in the Netherlands, ID turned out to be an entirely different kind of wedge. While educated Christians, who felt uncomfortable with a young Earth, welcomed ID as an acceptable alternative version of their religious orthodoxy, helping them to combine their faith with scientific evidence, young-Earth creationists did not appreciate their pro-ID efforts. The latter became increasingly worried about the rejection of the literal meaning of Genesis as a first step towards the rejection of the moral authority of the Bible.

At the same time, Knevel noticed that Cees Dekker, who had at first been defending ID, started publicly doubting its scientific merit, calling himself an evolutionary theist. Knevel, who thought highly of Dekker, was very much in doubt again. By 2007, he admitted that he did not yet know what position to take, putting himself somewhere between ID and theistic evolution (Knevel 2007, 237). 


\section{Shared anti-evolutionism}

An issue about which Knevel felt less hesitant was his resentment of "evolutionism", “Darwinism”, and “neo-Darwinism” (Knevel 2007, 198, 227, 235). Knevel genuinely believed that creationists like Michael Behe had come across natural phenomena that could not be explained by evolutionary theory (Knevel 2007, 198, 228). He thought, following most American creationists, that the mechanism of random mutation in combination with natural selection could be compared to a tornado whirling through a junkyard, thus creating a fully functioning Boeing 747 (Knevel 2007, 236). Knevel thereby completely negated the creative power of selective retention (Dawkins 2006). It was no wonder that Knevel declared that, for him, "evolution with random mutation and selection does not exist" (Knevel 2007, 237).

Knevel was certainly not the only person within the EO who rejected evolutionary theory. In 2007, an incident revealed that anti-evolutionary sentiments were still riding high within the evangelical broadcasting organization. On July 27, 2007, Gerdien de Jong, an evolutionary biologist at Utrecht University in the Netherlands, published an article on the weblog of biologist Gert Korthof, evolutie.blog.com. In this article she revealed how the EO had systematically and deliberately edited the BBC documentary The Life of Mammals, made and presented by David Attenborough. De Jong had carefully compared the DVDs sold by the EO with the original BBC DVDs and had found that the EO had cut out all references to evolution and to periods of millions of years and had altered the commentary in translation. The tenth episode, on humans, in which Attenborough discussed the relatedness of humans with apes, was left out entirely. This was all done without informing the viewers of the changes, an action that De Jong considered to be censorship. The exposé by De Jong was reported to the Algemeen Nederlands Persbureau (General Dutch Press Office) and, consequently, drew a great deal of media attention. ${ }^{38}$ Henk Hagoort, who had been promoted to director of the EO 
in March 2006, replacing Knevel and two others (Knevel 2007, 92), responded laconically to the charges. He said that editing documentaries this way was common practice in the world of television, and he was sure that the media storm would soon blow over. ${ }^{39}$

De Jong, however, did not intend to let this affair pass without further actions. At first, neither the BBC nor Attenborough made much of a fuss about the EO's editing the documentaries. In response to their lack of concern, De Jong, together with a colleague from Leiden University, Hans Roskam, organized a petition in which they asked the BBC to demand that the EO at least warn its viewers that the documentaries had been edited to conform to the aims and scope of the EO. ${ }^{40}$ The petition was signed by 379 scientists and sent to both the BBC and David Attenborough. ${ }^{41}$ In a radio debate with de Jong, Hagoort explained that the EO had been editing documentaries for decades and that the BBC had been aware of it. Moreover, the logo of the EO was clearly visible so that the viewers knew what to expect, and that certainly was not evolutionary theory. Hagoort bluntly stated that he himself did not believe that humans were descended from apes. ${ }^{42}$ A couple of days later, David Attenborough responded to the petitioners in a letter, writing that he regretted the changes the EO had made to his documentary. ${ }^{43}$ This letter even received some attention in the British media. ${ }^{44}$ More than a month later, a letter to the organizers of the petition from the $\mathrm{BBC}$ acknowledged that the $\mathrm{BBC}$ allowed local broadcasters to edit its material. In the case of the $\mathrm{EO}$, however, the BBC had requested that it withdraw the edited Life of Mammals DVDs from circulation ${ }^{45}$, which the EO did. ${ }^{46}$ In the meantime, the EO itself had formed a committee to evaluate the incident. This committee advised the EO that it should no longer secretly edit natural history documentaries. $^{47}$

The EO had its reasons for doctoring any material referring to evolution or evolutionary theory. On the occasion of its 40th anniversary in 2007, the EO had conducted a poll of the 
religious experiences of its almost half a million members ${ }^{48}$. The results, published in April 2007, showed that 61 percent of the respondents (with a 33 percent response rate ${ }^{49}$ ) believed that God had created the Earth in six 24-hour days. That was 8 percent more than in a poll the EO had conducted ten years before. Another 32 percent believed that God had created the world, but not necessarily in six days. Only 1 percent thought that God had used evolution in order to create life on Earth. ${ }^{50}$ This showed that a large proportion of the members of the EO still identified with the young-Earth creationism that the broadcasting group had promoted so intensively three decades earlier. In 2005, Knevel had already recognized that the EO's grassroots support contained a great number of what he called "intuitive creationists", since only 38 percent of the respondents regarded the origin of the world as an important aspect of their faith. ${ }^{51}$ Later, when he had accepted the scientific evidence for an old Earth, Knevel also expressed his regret - and felt partly to blame - for the fact that in the 1970s, the EO had gone along so enthusiastically with the American young-Earth movement (Knevel 2007, 234). Thirty years later, the effects of these developments still registered. Soon, Knevel would experience these effects personally.

\section{Knevel's heresy}

Today, Andries Knevel is no longer a director of the EO, but he is still considered a very prominent, representative figure. This means that when Knevel shares his opinions in public, people tend to think that he speaks for the EO. This is exactly what happened when, on February 3, 2009, on an EO television program, Knevel read a typed statement in which he confessed that he was no longer a young-Earth creationist and that he was sorry for misleading people. His statement read as follows (and the words crossed out here are the ones Knevel crossed out): 
1) I used to believe that creation had taken place in 6 times 24 hours and I was a creationist. Not long ago, I believed in Intelligent Design. But not anymore. Now I believe in evolution.

2) I recant all my earlier statements and acknowledge that I have led my children and viewers astray-along a certain trail. I regret that. And I also regret the part that the EO has played in this in the past.

3) I choose for credibility and faith. Therefore, I shall talk openly to everybody to get to the truth. And never believe in or speak of fairytales or pseudo-sciences again.

4) Faith and Science do not exclude each other, but keep on reinforcing and questioning one another. Both have their own truth, meaning and credibility.

5) With all my heart, I still believe in God, the creator of heaven and Earth, and Jesus Christ as savior and lord of this world.

In his own handwriting, he added:

6) I find it very peculiar that so many men of learning are religious.

I believe, Andries Knevel ${ }^{52}$ [my translation]

He then signed the document on the air and declared: "This is a beautiful statement". 53

Following Dekker, Knevel had moved towards theistic evolution, but, unlike Dekker, Knevel was not an academic. He had become the face of an organization the majority of whose members thought that it supported, or even shared, their creationist beliefs. Unsurprisingly, those members were not amused. They felt insulted by the way Knevel had presented his new 
convictions as a result of an improved judgement, a step beyond young-Earth creationism. Moreover, they could not accept that 'their' EO had wandered off the straight path. ${ }^{54}$ The impression that Knevel had spoken on behalf of the EO was reinforced in Trouw, a Dutch newspaper, by an article with the title, "EO lets go of creation story", ${ }^{55}$ Members contacted the EO in great distress, with some threatening to cancel their subscriptions. In a television show on February 5, Arjan Lock, the new director of the EO, tried to ameliorate the situation by insisting that Knevel did not personify the EO. ${ }^{56}$

That same evening, on another TV channel, Bert Dorenbos, who had served for almost 13 years as the director of the EO (1974-1987), called Knevel's statement an "insult to God" and "an act of aggression". 57 Another ex-employee of the EO, Frank van der Zwan, set up a weblog on which he demanded apologies from both Knevel and the EO. First, he urged members to annul their membership if Knevel and the EO did not comply, but after some reprimanding remarks from visitors to his site ("this is grist on the mill of Satan"), he dropped this "unchristian" part. ${ }^{58}$ Van der Zwan nevertheless got what he wanted. On February 14, Knevel apologized on the air for the arrogant way in which he had made his convictions public. He also affirmed that his views were not those of the EO ${ }^{59}$ He repeated the same message in a open letter that he wrote for Visie (Vision), the EO magazine. ${ }^{60}$ Nevertheless, the damage was done. Also on February 14, Bert Dorenbos wrote an open letter in which he resented the path the EO seemed to have taken, directed by people like Dekker and Knevel. ${ }^{61}$ Five days later, Dorenbos advised orthodox Christians to pray and fast during Lent in order to put the EO on the right track again. ${ }^{62}$ On March 18, a news program reported that the EO was undergoing a great crisis. ${ }^{63}$ Almost one month later, on April 10, Knevel again expressed his regret for signing the statement. He called it a moment of weakness and said that he had never intended to offend sincere creationist believers. ${ }^{64}$ 
Today, the EO seems entirely divided on the issue of creation. On one hand, most of its members still uphold the young-Earth interpretation that the EO had unanimously favored during the first ten years of its existence. On the other hand, prominent orthodox Christians are looking for a way to maintain their faith and, simultaneously, to accommodate the facts of science, with an old Earth and evolution as its most problematic components. At one point, some of them, like Dekker and Knevel, believed that ID offered them the ideal solution. To them, ID appeared to be a scientifically respectable alternative to young-Earth creationism and a welcome mediator between Christian orthodoxy and science. This honeymoon did not last very long because the scientific deficiency of ID soon became evident; however, the step had been made, and there was no turning back. Young-Earth creationism was no longer an option, and this fact brought people like Knevel into conflict with a young-Earth creationist community that was becoming more and more self-aware (see below). In the Netherlands, ID had indeed worked as a wedge, but not in the way Phillip Johnson and his co-workers of the Center for Science and Culture (CSC) had in mind. In a context different from the United States, the strategy of ID has failed miserably. By easing the transition of prominent creationists to becoming theistic evolutionists, ID had truly become a Dutch wedge.

\section{Young-Earth creationists unite}

\section{Sleeping dogs awake}

By the end of the 1970s, creationists in the Netherlands were confident that their religious views were dominant among orthodox Christians and their organizations. At the same time, they did not feel threatened by any influence from outside the orthodox community, since they could operate freely within the isolation of their own subculture. For almost 30 years, creationism disappeared from the public arena, only to return when creationists started to feel provoked. Suddenly, creationism became very visible again. 
Of course, Knevel's statement on television in which he denounced his faith in young-Earth creationism elicited a wave of criticism by more orthodox believers. Knevel later told the press that he and his family had suffered tremendously because of the tone and multitude of responses. ${ }^{65}$ However, by the time Knevel put creationists on the defensive against his 'heresy', they had already become very active once more. In the last two months of 2008, they had been drawn out into public not by theological struggles within the orthodox community, but by the planned year of commemorating the life and work of Charles Darwin. As soon as creationists realized that Darwin and evolutionary theory would be celebrated extensively in 2009, not only within the scientific community but also in the public arena, they initiated projects to counterbalance the impact of these festivities. In this way, they hoped to inform a large audience that there existed an alternative to the purely naturalistic account of 'Darwinism'. One project in particular drew a great deal of media attention.

\section{Distribute the word}

By the beginning of November 2008, the first reports on this project appeared in Christian newspapers. ${ }^{66}$ Kees van Helden, the president of the creationist group Bijbel en Onderwijs (Bible and Education) $^{67}$, was rallying financial support to print an eight-page pamphlet with the title, Evolutie of Schepping. Wat geloof jij? (Evolution or creation. What do you believe?). Once printed, the document was to be distributed by the postal services to every household in the Netherlands around February 12, 2009, the 200th anniversary of Charles Darwin's birthday. A committee of recommendation, consisting mainly of Protestant vicars, had been assembled $^{68}$, and the project was backed by 30 creationist organizations from both the Netherlands and Belgium. ${ }^{69}$ All information concerning the project could - and still can - be found on the website that was constructed especially for the occasion, www.creatie.info (Blancke 2009). 
On November 18 and 19, 2008, other newspapers started covering the project ${ }^{70}$, but the great breakthrough in media coverage came on November 20,2008, when one of its supporters, Johan Huibers, appeared on Dutch national television. ${ }^{71}$ Johan Huibers was already wellknown in the Netherlands. Two years before, he had finished building an 'ark' which, at this writing, he still uses as a traveling exhibition to deliver the word of God. ${ }^{72}$ Having already welcomed over 300,000 visitors on board, the popular response has encouraged him to build a second, even bigger ark that will allow him to travel overseas. As Huibers is already a wellknown creationist, he was the ideal person to introduce the project to a larger audience on television. He described creationism and evolutionism as two kinds of faith but said that only his Christian faith includes an eternal afterlife. Moreover, he believes that a balance should exist between creationism and evolutionary theory in school biology classes so that students can make an informed choice. When the moderator inquired whether there had been any dinosaurs on the ark, Huibers answered: "Only the little ones".

In December, some students at Utrecht University responded to this sudden outburst of creationist activity by producing and selling stickers that people could put on their mailboxes. The message on the sticker read, "No, creationism - Yes, Darwin". This way, people could make clear that they did not want to receive the pamphlet. The stickers turned out to be a great success and were sold out by the end of January $2009 .{ }^{73}$ At around the same time, it became clear that the stickers had not been bought in vain. Van Helden had raised sufficient money (but not all that was needed): on January 30 the first pamphlets were rolling off the press. ${ }^{74}$ The pamphlet, Evolutie of Schepping, promises to be "life-saving". It consists of eight pages, full of colored pictures and drawings, and presents a hodgepodge of American creationist arguments and ideas. The pamphlet characterizes evolutionary theory as a historical science that cannot be proven in principal. One cannot, it asserts, perform repeatable experiments to 
test explanations for the origin of human beings; one can only try to explain what happened, and these explanations are easily replaced by others. Next, two lines of evidence that support evolutionary theory are discredited. First, the authors repeat the young-Earth creationist claim that the fossil record does not require an evolutionary approach because the different geological strata can just as easily be explained by a worldwide flood (Whitcomb \& Morris 1961). Second, they 'expose' Ernst Haeckel's nineteenth-century drawings of embryos as a fraud, borrowing this debunking of one of the so-called 'icons of evolution' from one of CSC's central leaders, Jonathan Wells (Wells 2000, 81-109). ${ }^{75}$ In the end, according to the pamphlet, the preference for evolution or biblical creation is not a matter of evidence but a matter of choice: "You have a choice: to believe what evolutionary theory says about the origin of humans or to believe what the Bible says. Belief in evolutionary theory means that there is no answer to important questions like: Where do I come from? Why am I here? and Where do I go when I die? If we believe in the Bible, then there are indeed answers to these important questions. Then we can know that God has created us out of love and has a plan for our life." ${ }^{, 76}$ [my translation]

While waiting for the pamphlets to be distributed, the creationist activists took advantage of the attention given to their project and made appearances in the Dutch national media as often as possible. For instance, on January 6, 2009, Tom Zoutewelle of the creationist organization Creaton ${ }^{77}$, was featured in the program by Andries Knevel that kicked off the Darwin year for the EO (see above) ${ }^{78}$ On January 17 , Kees van Helden appeared on a radio program in which he debated with Coen Brummer, one of the students behind the sticker campaign. ${ }^{79}$ The upheaval surrounding Andries Knevel's confession on February 3 offered the students the ideal opportunity to participate in the debate and have their voices heard. Kees van Helden was interviewed in a news report on the distress that Knevel had caused among orthodox 
Christians. At the end of the interview, Van Helden turned to the camera and addressed Knevel directly, saying, "Andries, I hope - and we pray for you - that you will restore your faith in creation as it says in the Bible". ${ }^{80}$ Bert Dorenbos, once president of the EO and today president of his own fundamentalist anti-abortion organization Schreeuw om Leven ${ }^{81}$ (Cry for life), condemned Knevel's theological turn in a television debate ${ }^{82}$. On February 12, he handed out 'oersoep' (primeval soup) in the square in front of the Dutch parliament to indicate what is wrong with evolutionary theory. ${ }^{83}$ On February 14, just after having offered his apologies on the radio, Andries Knevel interviewed two young-Earth creationists in his own radio show to demonstrate that he was still willing to listen to their arguments. The two creationists were Jan Rein de Wit of the organization called Oude Wereld ${ }^{84}$ (Old World) and Frans Gunnink of Mediagroep in Genesis ${ }^{85}$ (Media Group in Genesis), a Dutch spin-off of the large American young-Earth creationist organization, Answers in Genesis ${ }^{86}$.

Because of the national media exposure, the project was already a success when finally, on February 19, Van Helden proudly released the pamphlet and personally handed out copies to the people of Urk, his hometown. ${ }^{87}$ On Monday, February 23, the rest of households in the Netherlands received the pamphlet through the postal services. ${ }^{88}$ Not surprisingly, many people were not amused by this creationist enterprise and had set up initiatives to protest against it. One initiative asked people to send the pamphlet back to its maker, Kees van Helden. ${ }^{89}$ Another one was set up by Christians to apologize for the aggressive proselytizing of their fellow believers. ${ }^{90}$ Not all responses, however, were that polite. Van Helden began receiving anonymous hate mail in which even his life was threatened. ${ }^{91}$ Van Helden did not understand why his project caused so much distress when people generally did not react in the same manner even to the unsolicited 'pornography' (actually, an advertisement for an erotic 
store) that they sometimes received in the mail. ${ }^{92}$ Overall, however, Van Helden and his coorganizers were very pleased to attract as much attention as they could.

\section{The aftermath}

After almost 30 years of relative silence, the pamphlet project has explicitly put young-Earth creationism back on the Dutch religious map. The discussion about evolution versus creation has not only become a hot topic within the confines of the Dutch orthodox community, but has also found its way to the public sphere. It is no wonder that the organizers consider their project a huge success. In the weeks following the distribution of the pamphlet, Jan Rein de Wit $^{93}$, Frans Gunnink ${ }^{94}$, and Kees van Helden ${ }^{95}$ all expressed their great satisfaction with the response they received. The fact that by March 18 they were still 113,500 euro's short of paying the bill did not seem to bother them. On the contrary, Van Helden felt confident enough to begin pursuing his next goal: obtaining equal time in the school curriculum for both evolutionary theory and creationism. ${ }^{96}$

In the aftermath of the project, various polls have been taken to inquire what the Dutch people actually thought about evolution and creationism. A scientific poll, by Miller, Scott and Okamoto, published in Science in 2006, had already revealed that one out of four Dutch people did not accept evolutionary theory (Miller et al. 2006). New polls by newspapers have confirmed this number. Two of them indicated that one out of five Dutch people adhered to a young-Earth creationist view. ${ }^{97}$ Another poll even found that one out of four hold those views. That same poll also showed that no less than 42 percent of the Dutch population did not object to rendering equal time in school to both evolutionary theory and creationism. ${ }^{98}$ These results were highly encouraging for Kees van Helden and his collaborators, who have begun setting up a civic initiative to collect 40,000 signatures in support of a claim for equal time, to be sent to the Dutch parliament. ${ }^{99}$ With the support of 40,000 adults, such an initiative can be put on 
the agenda of the Parliament. Van Helden has never been shy in his effort to incorporate his religious views into the Dutch school curriculum. ${ }^{100}$ Religious groups in the Netherlands are already granted considerable freedom concerning the school curriculum within their own state-funded schools. There is no problem to teach creationism in orthodox schools, but Van Helden wants creationism discussed in public schools as well. After the success of the pamphlet project, he felt confident enough to promote his plans through political means. Later, however, little was heard of this project.

\section{Conclusions}

Creationism may have been relatively silent in the Netherlands for the last couple of decades, but it clearly is not dead. Within the protective atmosphere of their own communities, churches and organizations, creationists felt relatively safe from disturbing influences. However, both internal disputes and the Darwin-year festivities have provoked them into action. Today, the voices of creationists are ringing very loudly; creationists are even equal time for their views in the curriculum of public schools.

On one hand, young-Earth creationism in the Netherlands seems stronger than ever. On the other hand, however, the strategy of ID to act as a wedge to crack the log of naturalism seems to have failed entirely. In a setting different from the United States, the Netherlands, ID was not regarded a strategy to unite creationists of all kinds and smuggle creationism into schools, but rather as a possible way of reconciling science and Christian faith. This was especially true of some highly educated, prominent orthodox believers who, fed up with the naïve young-Earth creationism of their fellow believers, considered ID to be a religiously valid and scientifically sound alternative. Once they realized that ID had nothing to offer them, they quickly turned away from it toward even more liberal theological stances. By then, ID had caused, or at least had laid bare, a distinct fracture within the orthodox community itself. 


\section{Epilogue}

When I first submitted this paper, in July 2009, the Darwin year was nearly half way, so it was to be expected that the young-Earth creationists would continue to make themselves heard. On July 28, the Belgian newspaper De Standaard announced that the creationists were coming, meaning that the creationist leaflet was also to be distributed in Flanders (the Dutch speaking part of Belgium) ${ }^{101}$. This news was later denied by Johannes Multimedia, another participating organization behind the leaflet campaign, claiming that, instead, they would focus on the distribution of a second folder, Wat biedt toekomst? Evolutie of schepping? ${ }^{102}$ (What offers a future? Evolution or creation?) by the end of 2009. On November 20, they presented this new leaflet. ${ }^{103}$ In the meanwhile, various young-Earth creationist books have been published not only to address the shortcomings and immoral consequences of evolutionary theory, but also to argue against the heresy of Knevel and other liberal interpreters of the Bible (e.g. Hofman 2009, Wijnands 2009). One of these books, 95 stellingen tegen evolutie (95 theses against evolution) (Progenesis 2009), which is actually a translation from a Swiss book, was promoted by posting the 95 theses by the entrance of the VU University Amsterdam, just like Luther had allegedly posted his theses in $1517 .{ }^{104}$ It remains to be seen what the creationists will come up with now the Darwin year is officially over.

\section{Acknowledgements}

This research was supported by grant BOF08/24J/041 from Ghent University. The author would like to thank Johan Braeckman, Willem B. Drees, Barbara Forrest, Gert Korthof, and the two anonymous reviewers of Zygon for their helpful comments .

\section{References}


Behe, Michael J. 1996. Darwin's black box. The biochemical challenge to evolution. New York: Free Press.

1997. Intelligent Design. De zwarte doos van Darwin (with a foreword by A. van den Beukel). Baarn: Ten Have.

Blancke, Stefaan. 2009. "Dutch, Belgian creationist groups unite to bring anti-evolution message to six million.” Skeptical Inquirer 33(1): 7.

Centraal Bureau voor de Statistiek. 2008. Statistisch jaarboek 2008. Den Haag: Centraal Bureau voor de Statistiek.

Collins, Francis. S. 2006. De taal van God (originally in English: The language of God). Baarn: Ten Have.

Cornish-Bowden, A. and Luz Cárdenas, M. 2007. "The threat from creationism to the rational teaching of biology." Biological Research. 40: 113-122.

Curry, A. 2009. “Creationist beliefs persist in Europe.” Science 323: 1159.

Dawkins, Richard. [1986] 2006. The blind watchmaker. London: Penguin Books.

Dekker, Cees. 2005. "De terugkeer van ontwerp in de wetenschap.” In Schitterend ongeluk of sporen van ontwerp? Over toeval en doelgerichtheid in de evolutie (Glorious accident, or traces of design?), ed. Cees Dekker, Ronald Meester, and René van Woudenberg, 42-62. Kampen: Ten Have.

.2006. “Schiep God de mens of schiep de mens God?” in En God beschikte een worm. Over schepping en evolutie (And God prepared a worm), ed. Cees Dekker, Ronald Meester, and René van Woudenberg, 360-383. Kampen: Ten Have. 
. 2007. "Naar een Brave New World?” in Omhoog kijken in platland. Over geloven in de wetenschap (Looking up in Flatland), ed. Cees Dekker, René van Woudenberg, and Gijsbert van den Brink, 279-303. Kampen: Ten Have.

(ed.). 2008. Geleerd en gelovig. 22 wetenschappers over hun leven, werk en God. (Learned and religious), Baarn: Ten Have.

.2008. "Uit wat ik ben en was." in Geleerd en gelovig. 22 wetenschappers over hun leven, werk en God (Learned and religious), Cees Dekker, 317-337. Baarn: Ten Have.

Dekker, Cees and Ronald Meester. 2002. "Pleidooi voor een open houding ten aanzien van de historische oorsprong van het leven.” Skepter 15(4): 42-45. Also at http://www.skepsis.nl/iddiscussie-1.html.

Dekker, Cees, Ronald Meester, and René van Woudenberg (ed.). 2005. Schitterend ongeluk of sporen van ontwerp? Over toeval en doelgerichtheid in de evolutie (Glorious accident, or traces of design?) Kampen: Ten Have.

(ed.). 2006. En God beschikte een worm. Over schepping en evolutie (And God prepared a worm). Kampen: Ten Have.

Dekker, Cees, René van Woudenberg, and Gijsbert van den Brink (ed.). 2007. Omhoog kijken in platland. Over geloven in de wetenschap (Looking up in Flatland). Kampen: Ten Have.

Dembski, William A. 1999. Intelligent Design. The bridge between science and theology. Downers Grove: Intervarsity Press.

Enserink, Martin. 2005. "Evolution politics: Is Holland becoming the Kansas of Europe?" Science 308 (5727): 1394. 
Flipse, Ab. 2009. ““De schepping zou er even wonderbaar om zijn.' Geschiedenis van het evolutiedebat in gereformeerde en rooms-katholieke kring." In Botsen over het begin. Bavinck lezingen 2009 (Colliding over the beginning. Bavinck lectures 2009). ed. Koert van Bekkum and George Harinck, In press.

Forrest, Barbara and Paul R. Gross. [2004] 2007. Creationism's Trojan horse. The Wedge of Intelligent Design. New York: Oxford University Press.

Graebsch, Almut. 2006. "Polish scientists fight creationism.” Nature 433: 890-891.

Hofman, H.A. 2009 Het bittere conflict. Over schepping en evolutie in het jaar van Darwin en Calvijn.Soesterberg: Aspekt.

Hulspas, Marcel. 2002. “Twee geloven op een kussen. De schepping als intelligent ontwerp.” Skepter 15 (1). Also at: http://www.skepsis.nl/ontwerp.html.

Johnson, Phillip E. 1991 Darwin on trial., Downers Grove: Intervarsity Press. 1995. Reason in the balance. The case against naturalism in science, law and education., Downers Grove: Intervarsity Press.

Kjaergaard, Peter. 2008. "Western Front.” New Humanist. The magazine for free thinkers. 123(3): 39-41.

Knevel, Andries. 2007. Avonduren. Dagboek van een bewogen jaar (Evening hours). Baarn: Ten Have.

Kutschera, Ulrich. 2008. "Creationism in Germany and its possible cause.” Evolution: Education and Outreach 1: 84-86. 
Meester, Ronald. 2006. “Mijn God, ik weet niet wie Gij zijt, maar wel dat Gij niet zijt een god naar mensentrant" in: En God beschikte een worm. Over schepping en evolutie (And God prepared a worm). ed. Cees Dekker, Ronald Meester, and René van Woudenberg, 282-298. Kampen: Ten Have.

Miller, Jon D., Eugenie C. Scott, and S. Okamoto. 2006. "Public acceptance of evolution." Science 313: 765-766.

Miller, Kenneth R. 1999. Finding Darwin's God. A scientist's search for common ground between God and evolution. New York: Harper Collins.

Numbers, Ronald. 2006. The creationists. From scientific creationism to Intelligent Design. Expanded Edition. Cambridge, MA: Harvard University Press,.

Pennock, Robert T. 1999. Tower of Babel. The evidence against the new creationism.

Cambridge, MA: MIT Press. (ed.). 2001. Intelligent Design Creationism and its critics. Philosophical, theological and scientific perspectives. Cambridge, MA: MIT Press.

Progenesis. 2009. 95 stellingen tegen evolutie. Wetenschappelijke kritiek op het naturalistische wereldbeeld. Doorn: Johannes Multimedia.

Smedes, Taede A. 2005. “'Intelligent Design'. Is het wetenschap of theologie? Achtergronden van een groeiende controverse.” Nederlands Theologisch Tijdschrift 59: 106-123. . 2006. "Theologie, natuurwetenschap en het probleem van de menselijke maat." In En God beschikte een worm. Over schepping en evolutie (And God prepared a worm). ed. Cees Dekker, Ronald Meester, and René van Woudenberg, 101-113. Kampen: Ten Have. 
Smelik, Pieter. 2007. "Scheppingsgeloof of toevalsgeloof?” in: Omhoog kijken in platland. Over geloven in de wetenschap (Looking up in Flatland), ed. Cees Dekker, René van Woudenberg, and Gijsbert van den Brink, 165-180. Kampen: Ten Have.

Van den Beukel, Arie. 1990. De dingen hebben hun geheim. Gedachten over natuurkunde, mens en God (Things have their secrets). Baarn: Ten Have.

1994. Met andere ogen. Over wetenschap en het zoeken naar zin (With different eyes). Baarn: Ten Have.

. 2006. “De wereld: schepping of toevalstreffer?” In En God beschikte een worm. Over schepping en evolutie (And God prepared a worm). ed. Cees Dekker, Ronald Meester, and René van Woudenberg, 198-211. Kampen: Ten Have.

Van Woudenberg, René. 2002. Ontwerp en toeval in de wereld. (Design and chance in the World). Amstelveen: De Zaak Haes.

2003. Toeval en ontwerp in de wereld. Apologetische analyses. (Chance and design in the World. Apologetic analyses). Budel: Damon.

. 2006. "Houdingen inzake evolutie en schepping.", In En God beschikte een worm. Over schepping en evolutie (And God prepared a worm). ed. Cees Dekker, Ronald Meester, and René van Woudenberg, 180-197. Kampen: Ten Have.

Wells, Jonathan. 2000. Icons of evolution. Science or myth? Why much of what we teach about evolution is wrong. Washington DC: Regnery Publishing.

Whitcomb, John C. and Henry M. Morris. 1961. The Genesis flood. The biblical record and its scientific implications. Philadelphia: The Presbyterian and Reformed Publishing Company. 
Wijnands, Zeger. 2009. God of Darwin. Kan wetenschap om de Bijbel heen? Elburg:

\section{Ipenburg.}

Young, Matt and Taner Edis. (ed.). 2004. Why Intelligent Design fails. A scientific critique of

the new creationism., New Brunswick: Rutgers University Press.

\footnotetext{
${ }^{1} \mathrm{http}: / /$ www.ceesdekker.net/html/publications.html

${ }^{2}$ The original blog has been removed from the Internet. Fortunately, the text can be found on several other web sites. One of them is: http://www.kennislink.nl/web/show?id=132896.

${ }^{3}$ See the article in De Volkskrant, May 21, 2005:

http://www.volkskrant.nl/den_haag/article198440.ece/Minister_wil_debat_over_evolutie_en_schepping.

${ }^{4}$ http://www.kennislink.nl/web/show?id=132896.

${ }^{5} \mathrm{http} / / /$ www.uncommondescent.com/education/dutch-cabinet-supports-discussion-of-id/.

${ }^{6} \mathrm{http}: / /$ assembly.coe.int/Main.asp?link=/Documents/WorkingDocs/Doc07/EDOC11375.htm.

${ }^{7} \mathrm{http}: / /$ assembly.coe.int/Main.asp?link=/Documents/AdoptedText/ta07/ERES1580.htm

${ }^{8}$ For the American reader: the inaugural speech is a speech marking the beginning of one's professorship

${ }^{9} \mathrm{http}: / / \mathrm{www} . c e e s d e k k e r . n e t / f i l e s / o r a t i e s p e e c h . p d f, 18$.

${ }^{10} \mathrm{http}: / /$ www.ceesdekker.net/files/oratiespeech.pdf, 18.

${ }^{11}$ Michael Denton was once a CSC fellow (Forrest and Gross 2007). Today, however, he is no longer listed as such (http://www.discovery.org/csc/fellows.php).

${ }^{12} \mathrm{http} / / /$ www.cs.vu.nl/ rmeester; the VU University Amsterdam has distinct orthodox Protestant roots and is not to be confused with the University of Amsterdam, which is a state university.

${ }^{13}$ http://www.cs.vu.nl/ rmeester/oratievu.pdf, 18 .

${ }^{14} \mathrm{http}: / / \mathrm{www}$. skepsis.nl/id-discussie-2.html.

${ }^{15} \mathrm{http} / / / \mathrm{www}$.darwinanddesign.org/. Unfortunately, this website is no longer accessible.

${ }^{16} \mathrm{http}: / / \mathrm{www}$.uncommondescent.com/intelligent-design/not-just-an-american-phenomenon-the-recent-pragueid-conference/.

${ }^{17}$ http://www.discovery.org/csc/fellows.php.

${ }^{18} \mathrm{http} / / / \mathrm{www}$.discovery.org/a/2974. This article was not written by someone from the Discovery Institute, but by Ondrej Hejma for Associated Press. In reaction to this article, William Dembski wrote his own report of the conference, cited in notes 16 and 19.

${ }^{19} \mathrm{http}: / / \mathrm{www} . u n c o m m o n d e s c e n t . c o m /$ intelligent-design/not-just-an-american-phenomenon-the-recent-pragueid-conference.

${ }^{20}$ http://www.vpro.nl/programma/buitenhof/afleveringen/25203667/media/25781280/?bw=bb\&player=wmp\&me $\mathrm{dia}=25781280 \&$ refernr $=\&$ hostname $=\mathrm{www} \&$ portalid $=$ programmasites $\& \mathrm{x}=63 \& \mathrm{y}=14$.

${ }^{21}$ This rather strange title come from a passage in Jonah in the Old Testament. Jonah 4, 7 reads: 'But as morning dawned the next day God prepared a worm, and it so damaged the plant, that it withered' (New King James Version): http://www.biblegateway.com/passage/?book_id=39\&chapter=4\&version=50.

${ }^{22} \mathrm{http}: / / w w w . e o . n l / p r o g r a m m a / h e t e l f d e u u r / 2005-2006 /$ page/-/mediaplayer/index.esp?aflid=6939276.

${ }^{23}$ John 1, 1-3: 'In the beginning was the Word, and the Word was with God, and the Word was God. He was in the beginning with God. All things were made through Him, and without Him, nothing was made that was made.' (New King James Version):

http://www.biblegateway.com/passage/?book_id=50\&chapter=1\&version=50.

${ }^{24} \mathrm{http}: / / w w w . n d . n l / a r t i k e l e n / 2006 /$ april/14/cees-dekker-ik-ben-geen-id-aanhanger.

${ }^{25}$ The influence of Collins' book on Dekker was pointed out to me by Gert Korthof (email, May 5, 2009).

${ }^{26}$ The title refers to the novel by Edward A. Abott from 1884, called Flatland. A novel of many dimensions (Dekker et al. 2007, 9). The book can be found on: http://www.geom.uiuc.edu/ banchoff/Flatland.

${ }^{27} \mathrm{http}: / / w w w . e o . n l / p r o g r a m m a / h e t e l f d e u u r / 2007-2008 /$ page//mediaplayer/index.esp;jsessionid=331B7E8AE5187799FF9AE73983D962B2 . mbase02 aflid=8970397. ${ }^{28}$ The website of Reformatorisch Dagblad cannot be consulted on Sundays. When you try to connect to their site, you get the following message: '[We are] Glad that you are interested in refdag.nl, the news site of the Reformatorisch Dagblad. Today is Sunday. We devote this day especially to the service of God. We consider
} 
Sunday to be a day of rest, an assignment by God, a gift for which we can be grateful. That is why today we do not bring our site up to date.' http://www.refdag.nl (only on Sundays, of course).

${ }^{29} \mathrm{http}: / / \mathrm{www}$. refdag.nl/artikel/1370585/\%26bdquo\%3BGenesis+en+evolutie+gaan+goed+samen\%26rdquo\%3B. html, and http://www.refdag.nl/artikel/1370886/Uitleg+Dekker+als+theistisch+evolutionist.html.

${ }^{30}$ Schitterend ongeluk: http://www.eo.nl/programma/hetelfdeuur/2004-

2005/page/Het_Elfde_Uur/episode.esp?episode=5634811; En God beschikte een worm:

http://www.eo.nl/programma/hetelfdeuur/2005-2006/page///mediaplayer/index.esp?aflid=6939276; Omhoog

kijken in Platland: http://www.eo.nl/programma/hetelfdeuur/2007-2008/page/-

/mediaplayer/index.esp;jsessionid=331B7E8AE5187799FF9AE73983D962B2. $\mathrm{mmbase} 02$ ?aflid=8970397.

${ }^{31}$ The program of the presentation on June 8, 2005, can be found on:

http://www.wetenschapsforum.nl/index.php?showtopic $=9785$.

${ }^{32}$ The text of five of the six episodes can be consulted on: http://users.skynet.be/fa390968/_Adam_aap.doc

${ }^{33} \mathrm{http}: / / \mathrm{www}$.wildersmith.org.

${ }^{34} \mathrm{http}: / /$ www.kennislink.nl/web/show?id=131881.

${ }^{35} \mathrm{http}: / /$ www.eo.nl/programma/kerkinbeweging/2004-2005/page/-/mediaplayer/index.esp?aflid=6325049.

${ }^{36} \mathrm{http}: / /$ www.eo.nl/programma/kerkinbeweging/2004-2005/page///mediaplayer/index.esp?aflid=6325049.

${ }^{37} \mathrm{http}: / / \mathrm{www} . e o . n l /$ programma/kerkinbeweging/2004-2005/page/-/mediaplayer/index.esp?aflid=6325049.

${ }^{38} \mathrm{http}: / /$ evolutie.blog.com/2007/07/.

${ }^{39} \mathrm{http}: / /$ www.refdag.nl/artikel/1310752/EO+laconiek+onder+aantijging+censuur.html.

${ }^{40} \mathrm{http}: / /$ www.refdag.nl/artikel/1313633/Petitie+biologen+tegen+\%22\%3BEO-censuur\%22\%3B.html; http://www.trouw.nl/groen/article1675414.ece/Petitie_biologen_tegen_censuur_EO_in_natuurfilms_.html.

${ }^{41} \mathrm{http}: / /$ www.refdag.nl/artikel/1316151/BBC+krijgt+honderden+handtekeningen+tegen+censuur.html.

${ }^{42} \mathrm{http}: / /$ www.ochtenden.nl/programmas/22955152/afleveringen/32971728/;

http://evolutie.blog.com/2007/09/24/.

${ }^{43}$ http://evolutie.blog.com/2007/10/03/.

${ }^{44} \mathrm{http} / / / \mathrm{www}$. telegraph.co.uk/scienceandtechnology/science/sciencenews/3309018/Creationists-rewrite-natural-

history.html and http://www.timesonline.co.uk/tol/comment/faith/article2598138.ece.

${ }^{45} \mathrm{http}: / /$ home.planet.nl/ gkorthof/blog/brief-BBC-WW-dd-19-Nov-antw.jpg.

${ }^{46} \mathrm{http} / / /$ www.refdag.nl/artikel/1330895/EO+haalt+natuurseriedvd+uit+de+verkoop.html.

${ }^{47}$ Email by Gert Korthof, May 5, 2009.

${ }^{48}$ The Netherlands has a population of 16.4 million people. 20 percent of the Dutch people above the age of twelve consider themselves Protestants (Centraal Bureau voor de Statistiek 2008). This amounts to about 3 million people. Therefore, more than one out of six is a member of the EO. In 2007, with its half a million members, the EO was the second largest medium network in the Netherlands (today, the EO comes in third).

${ }^{49} \mathrm{http}: / /$ www.refdag.nl/artikel/1301282/EO+schuift+geleidelijk+op+naar+het+midden.html.

${ }^{50} \mathrm{http}: / /$ www.eo.nl/algemeen/darwin/page/EO_leden_over_schepping/articles/article.esp;jsessionid=DD4911453 C292E17C12E9C769D38D164.mmbase01? article $=10136630$.

${ }^{51} \mathrm{http} / / / \mathrm{www} . e o . n l /$ programma/kerkinbeweging/2004-2005/page/-/mediaplayer/index.esp?aflid=6325049.

${ }^{52} \mathrm{http} / / / \mathrm{www}$. trouw.nl/religie-filosofie/article2023282.ece/De_evolutie_van_de_Evangelische_Omroep.html;

${ }^{53} \mathrm{http} / / / \mathrm{www} . e o . n l /$ programma/tzaljemaargebeuren/2008-2009/page/-/mediaplayer/index.esp?aflid=10216490.

${ }_{54}^{54} \mathrm{http}: / /$ www.novatv.nl/page/detail/uitzendingen/6691.

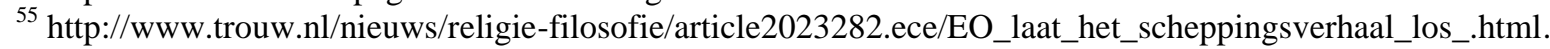

This title of this page has been altered.

${ }^{56} \mathrm{http}: / /$ pauwenwitteman.vara.nl/Archief-

detail.113.0.html?\&no_cache=1\&tx_ttnews $\% 5$ btt_news $\% 5 \mathrm{~d}=2410 \& \mathrm{tx} \_$ttnews $\% 5 \mathrm{bcalendarYear} \% 5 \mathrm{~d}=2009 \& \mathrm{tx}$ ttnews $\% 5$ bcalendarMonth $\% 5 \mathrm{~d}=2 \& \mathrm{tx} \_\mathrm{ttnews} \% 5 \mathrm{~b}$ backPid $\% 5 \mathrm{~d}=111$.

${ }^{57} \mathrm{http}: / /$ dewerelddraaitdoor.vara.nl/Uitzendingen-

detail.630.0.html?\&tx_ttnews[tt_news]=4588\&tx_ttnews[month]=02\&tx_ttnews[year]=2009\&cHash=debcb30e 14.

${ }^{58} \mathrm{http}: / /$ eoherroep.blogspot.com. The blog has been removed from the internet and therefore cannot be consulted any longer.

${ }^{59} \mathrm{http} / / / \mathrm{www} . e o . n l /$ programma/eonl/2008-2009/page/-/mediaplayer/index.esp?aflid=10238204.

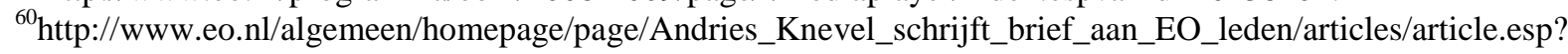
article $=10238027$.

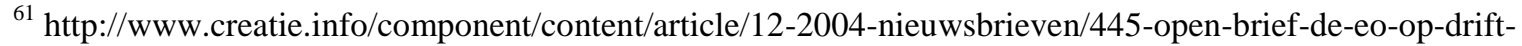
geraakt-door-drs-lp-dorenbos.html.

${ }_{62}$ http://www.nd.nl/artikelen/2009/februari/19/veertig-dagen-bidden-en-vasten-voor-eo.

${ }^{63} \mathrm{http}: / /$ www.novatv.nl/page/detail/uitzendingen/6806/. 
${ }^{64} \mathrm{http}: / /$ player.omroep.nl/?aflID=9245137.

${ }^{65} \mathrm{http} / / / \mathrm{www} . v 0 l k s k r a n t . n 1 / b i n n e n l a n d / a r t i c l e 1175210 . e c e / K n e v e l \_$Het_was_een_heel_zware_tijd.

${ }^{66} \mathrm{http}: / /$ www.refdag.nl/artikel/1371834/Huis-aan-huisactie+in+kader+van+Darwinjaar.html.

${ }^{67} \mathrm{http}: / /$ www.bijbelenonderwijs.nl/index.php.

${ }^{68} \mathrm{http}: / /$ www.creatie.info/in-de-media/293-comitevanaanbevelingondersteuntditinitiatief.html. Unfortunately, this page is no longer accessible.

${ }^{69} \mathrm{http}: / / \mathrm{www} . c r e a t i e$. info/in-de-media/386-meewerkende-organisaties.html.

${ }^{70} \mathrm{http}: / /$ www.volkskrant.nl/wetenschap/article1094941.ece/Plannen_christenen_voor_actie_tegen_Darwin; http://www.edestad.nl/page/Inter-nationaal/Geestelijk-leven/Christenen-voeren-actie-tegen.287462.news.

${ }^{71} \mathrm{http}: / /$ pauwenwitteman.vara.nl/Archief-

detail.113.0.html?\&no_cache=1\&no_cache=1\&tx_ttnews[tt_news]=1969\&tx_ttnews[backPid] $=111 \& c H a s h=5 b$ $07262 \mathrm{dc} 1$.

${ }^{72} \mathrm{http}: / /$ www.arkvannoach.com.

${ }_{73}^{73} \mathrm{http} / / / \mathrm{www}$. neecreationisme-jadarwin.nl/.

${ }^{74}$ http://www.ad.nl/ad/nl/1012/Binnenland/article/detail/250071/2009/01/30/Brochure-tegen-evolutieleer.dhtml ; http://www.nrc.nl/binnenland/article2137332.ece/Nederlanders_krijgen_brochure_tegen_evolutieleer; http://www.telegraaf.nl/binnenland/3130335/_Brochure_tegen_evolutieleer__.html;

http://video.google.com/videoplay?docid=-2825454305888393406.

${ }^{75}$ For a critical analysis of this claim, see Forrest \& Gross 2004, 103-106.

${ }^{76} \mathrm{http} / / / \mathrm{www}$. creatie.info/books/bookid/3.

${ }^{77} \mathrm{http}: / / \mathrm{www} . c r e a t o n . n l ;$ Creaton is one of the participating organizations in the pamphlet project, see http://www.creatie.info/in-de-media/386-meewerkende-organisaties.html.

${ }^{78} \mathrm{http}: / /$ www.eo.nl/programma/hetelfdeuur/2008-2009/page///mediaplayer/index.esp?aflid=10135815.

${ }^{79} \mathrm{http}: / /$ player.omroep.nl/?aflID=8716214\&start=00:31:00.

${ }^{80} \mathrm{http}: / /$ www.novatv.nl/page/detail/uitzendingen/6691.

${ }^{81} \mathrm{http}: / / \mathrm{www} . s c h r e e u w o m l e v e n . n l ;$ Schreeuw om Leven is also one of the participating organizations, see http://www.creatie.info/in-de-media/386-meewerkende-organisaties.html.

$82 \mathrm{http}: / /$ dewerelddraaitdoor.vara.nl/Uitzendingen-

detail.630.0.html?\&tx_ttnews[tt_news]=4588\&tx_ttnews[month]=02\&tx_ttnews[year]=2009\&cHash=debcb30e 14.

${ }^{83} \mathrm{http}: / /$ www.refdag.nl/multimedia/397/Schreeuw+om+Leven+serveert+oersoep+in+Den+Haag.html; http://www.nd.nl/artikelen/2009/februari/12/waterige-oersoep-van-dorenbos.

${ }^{84} \mathrm{http}: / / \mathrm{www}$. oude-wereld.nl; Oude Wereld also participates in the pamphlet project, see

http://www.creatie.info/in-de-media/386-meewerkende-organisaties.html.

${ }^{85} \mathrm{http}: / /$ www.scheppingofevolutie.nl; participating organization, see ://www.creatie.info/in-de-media/386meewerkende-organisaties.html.

${ }_{86}^{86} \mathrm{http}: / / \mathrm{www}$.answersingenesis.org.

${ }^{87} \mathrm{http} / / /$ www.omroepflevoland.nl/nieuws/recent?NewsKey=C0015919B28BD9A6C1257562003F6381; http://player.omroep.nl/?aflID=8926466\&start=00:14:49.

${ }^{88} \mathrm{http}: / /$ www.telegraaf.nl/binnenland/3319270/_Scheppingsleer_in_de_bus_.html?p=7,1; http://www.depers.nl/binnenland/287232/Scheppingsleer-ter-discussie.html; http://www.dag.nl/opvallend/brochure-scheppingsleer-deurmat-231276; http://www.edestad.nl/page/Internationaal/Geestelijk-leven/Brochure-scheppingsleer-op-de-deurmat.325713.news;

http://www.brabantsdagblad.nl/algemeen/geestelijkleven/4554650/Brochure-scheppingsleer-op-de-deurmat.ece; http://www.parool.nl/parool/nl/266/Religie-en-spiritualiteit/article/detail/181023/2009/02/23/Schepping-op-dedeurmat.dhtml; http://www.trouw.nl/nieuws/religie-

filosofie/article2037954.ece/Brochure_scheppingsleer_op_de_deurmat.html;

http://www.katholieknederland.nl/actualiteit/2009/detail_objectID684770_FJaar2009.html.

${ }^{89} \mathrm{http}: / / \mathrm{www}$. terugnaarjemaker.nl.

${ }^{90} \mathrm{http}: / / \mathrm{www}$. sorryvoorditgebaar.nl. Unfortunately, this page is no longer accessible.

${ }^{91} \mathrm{http} / / / \mathrm{www}$. refdag.nl/artikel/1393935/Man+achter+folder+schepping+met+dood+bedreigd.html; http://www.telegraaf.nl/binnenland/3329408/_Maker_anti-darwin_folder_bedreigd_.html?p=1,1;. Also some Belgian newspapers and magazines reported this: http://www.knack.be/nieuws/europa/doodsbedreiging-voorcreationist/site72-section25-article29882.html;

http://www.demorgen.be/dm/nl/990/Buitenland/article/detail/719465/2009/02/24/Nederlander-achter-antiDarwinfolder-met-dood-bedreigd.dhtml.

${ }_{92} \mathrm{http}: / /$ www.omroepflevoland.nl/nieuws/recent?NewsKey=C0015919B28BD9A6C1257562003F6381.

${ }^{93} \mathrm{http}: / /$ player.omroep.nl/?aflid=9022642. 
${ }_{94}^{94}$ http://www.radio1.nl/contents/4243-scheppingsfolder-een-succes.

${ }^{95} \mathrm{http}: / / \mathrm{www}$. omroepflevoland.nl/nieuws/nieuwsbericht?NewsID=57800.

${ }^{96} \mathrm{http}: / /$ www.refdag.nl/artikel/1398726/Evolutie+en+schepping+beide+in+biologieonderwijs.html.

${ }^{97} \mathrm{http}: / /$ static.telegraaf.nl/media/090225.onderzoek.pdf,

http://www.telegraaf.nl/binnenland/3336037/_Een_vijfde_gelooft_niet_in_Darwin_.html?p=4,1;

http://www.synovate.nl/pdf/EvolutieOfSchepping.pdf.

${ }^{98} \mathrm{http}$ //www.teamvier.nl/Marktonderzoek/Folder-Evolutie-of-schepping-vaak-ongelezen-de-prullenbak-in-1maart-2009.html. However, only 401 people were interviewed, which is not a very significant number. See also: http://www.volkskrant.nl/binnenland/article1155886.ece/Debat_over_schepping_ontbrandt_door_folder.

${ }^{99} \mathrm{http}: / /$ www.omroepflevoland.nl/nieuws/nieuwsbericht?NewsID=57800.

${ }^{100} \mathrm{http}: / /$ www.bijbelenonderwijs.nl/index.php; http://www.destentor.nl/stentortv/regionieuws/article4531441.ece

${ }^{101} \mathrm{http}: / / \mathrm{www}$. standaard.be/artikel/detail.aspx ?artikelid=9B2D3SHQ\&word=creationisten

$102 \mathrm{http} / / /$ www.creatie.info/books/bookid/21

${ }^{103} \mathrm{http}: / /$ www.reformatorischeomroep.nl/media_archief.html?player=WMP\&series_id=5\&delivery_id=858\&sub mit=Afspelen

${ }^{104} \mathrm{http}: / /$ www.reformatorischeomroep.nl/media_archief.html?player=WMP\&series_id=5\&delivery_id=858\&sub mit=Afspelen 